УДК: $353+308$

DOI: https://doi.org/10.32689/2618-0065-2020-2(4)-90-102

Демченко Володимир Миколайович, кандидат філологічних наук, доцент, доцент кафедри державного управління і місцевого самоврядування Херсонського національного технічного університету, 73008, м. Херсон, Бериславське Шосе, 24, d.vovchyk@gmail.com, 050-1499345, https//orcid.org/0000-0003-1841-7798

\title{
ЕТНОСОЦІАЛЬНИЙ ЧИННИК РЕГІОНАЛЬНОГО УПРАВЛІННЯ (ретроспективний огляд на прикладі Херсонської області)
}

Анотація. У статті проаналізовано особливості системи етнодуховних цінностей жителів Херсонщини. Простежено історію формування етнічного складу регіону з початку його масового офіційного заселення до сьогодні в мовній, освітній, релігійній площинах, послуговуючись архівними матеріалами та працями регіональних істориків. У межах такого дослідження проаналізовано етнічні потоки заселення «нових земель» наприкінці XVIII століття, причому засвідчено принципове переважання та автохтонність українців, що пов’язано з попереднім існуванням козацьких поселень. У межах дослідження результатів переписів регіону від 1898 до 2001 рр. визначено тенденцію до зростання частки українців, зокрема й у місті, та, відповідно, носіїв української мови як рідної.

Паралельно досліджено розвиток білінгвістичної опозиції «українська мова (місцева) - російська мова (метрополійна)», що властиво імперській і постімперській ситуаціям, коли мова колонії поступалася мові метрополії якісно й кількісно - в освіті, управлінні, релігії, культурі. І це відбувається в умовах кількісного домінування українців-аборигенів. Зауважено, що сьогодні імперська російська мова залишається активною в неформальному спілкуванні в міських умовах і в деяких інформаційних джерелах (зокрема в Інтернеті). Однак акцентовано на тому, що сьогодні мовна опозиція вже не впливає категорично на загальну світоглядну опозицію серед місцевого населення, що поділяється на євроспрямованих і російськоспрямованих осіб.

Зроблено висновки, що наприкінці XIX століття в регіоні сформувалася українська етнічна більшість, через що логічно говорити і про домінування українських етнодуховних цінностей. Постійне поповнення Херсона, Одеси та Миколаєва за рахунок сільського населення (переважно українського) формувало потенційне середовище громадян майбутньої незалежної держави, 
незважаючи на їх двомовність і віднесеність певної частини до «радянського народу».

Ключові слова: Херсонщина, перепис, селяни, міщани, система етнодуховних цінностей, імперські орієнтири.

Demchenko Volodymyr Mykolayovych, candidate of Philological Sciences, Associate Professor, Associate Professor of Department of Public Administration and Local Self-Government, Kherson National Technical University, Kherson, Beryslav Highway, 24, d.vovchyk@gmail.com, 050-1499345, https//orcid.org/00000003-1841-7798

\section{ETHNOSOCIAL FACTOR OF REGIONAL GOVERNANCE (retrospective review on the example of Kherson region)}

Abstract. The article analyzes the features of the system of ethno-spiritual values of the residents of Kherson Oblast. The history of formation of the ethnic composition of the region from the beginning of its mass official settlement till present in the language, educational and religious spheres using archive material and works of regional historians is traced. This study analyzes the ethnic flows of "new lands" settlement at the end of the XVIII century and certifies the principal dominance and autochthony of Ukrainians that is connected with previous existence of Cossack settlements. As part of the study of results of census survey in the region from 1898 to 2001, the tendency to increase in proportion of Ukrainians, in particular in the city, and, accordingly, of Ukrainian native speakers is determined.

In parallel, the development of bilingual opposition "Ukrainian (local) Russian (metropolitan)” is studied, which is typical of the Imperial and post-Imperial situations when the colonial language was inferior to the metropole language qualitatively and quantitatively - in education, management, religion and culture. This happens under conditions of quantitative dominance of native Ukrainians. It is noted that today the Imperial Russian remains active in informal communication in cities and in some information sources (in particular on the Internet). However, it is emphasized that today the language opposition no longer deeply affects the general worldview opposition among local population, which is divided into Europe-focused and Russia-focused people.

It is concluded that at the end of the XIX century, the Ukrainian ethnic majority was formed in the region, which makes it logical to speak of dominance of Ukrainian ethno-spiritual values. The constant replenishment of Kherson, Odessa and Mykolaiv by rural population (mainly Ukrainian) formed the potential environment for citizens of the future independent state, despite their bilingualism and affiliation of a certain part to the "Soviet people".

Keywords: Kherson Oblast, census survey, rural population, city population, system of ethno-spiritual values, Imperial guidelines. 
Постановка проблеми. Відомо, що Україна в 90-ті роки XX століття постала як найбільш неконфліктна держава пострадянського простору, оскільки провідний чинник вирішення етнодуховних проблем, зокрема й реального національного суверенітету, якого було досягнуто лише 2014 року, тоді було проігноровано (точніше, уникнуто) як соціально небезпечний в умовах того часу. При цьому ми не говоримо тут про свідомий негативний вплив колишньої метрополії - 3 90-х років тіньовий, з 2014-го - відкритий. Зрештою, питання етнічних духовних цінностей вирішувалося дуже повільно - еволюційно, тобто 3 поступовим «відходом» старих поколінь - носіїв попередньої культури - і не лише біологічним, але й моральним (багато хто 3 таких осіб переосмислив свої колишні пріоритети на користь українських).

Серед проблемних питань у цій сфері, якими є внутрішні - мовні, культурні, релігійні, освітні, визначаються й більшою мірою зовнішні маніфестування духовних цінностей народу за допомогою знакової системи, що фіксується в інформаційному просторі. Це, наприклад, топонімійна система, що зазнала принципової зміни лише через чверть століття існування України як унітарної національної держави (один із парадоксів постколоніальної країни), або медійна система, що довго ще буде послуговуватися й російською мовою також (радіо- та інтернет-простір), або мовна система, що давно потребує звільнення від штучних російськомовних нашарувань - як на рівні літературної мови (кальковані форми), так і в неофіційному спілкуванні (просторіччя, матизми, арготизми). Означені соціальні площини потребують державного втручання, яким $\epsilon$ останній ухвалений Закон про українську мову, що надалі потребує реального виконання й контролю.

Аналіз останніх досліджень і публікацій. Вивчення духовних етнічних орієнтирів у сфері державного буття властиве переважно зарубіжним ученим, серед яких - Р. Бенедикт, В. Сфімов, А. Інклес, М. Мід, Г. Хофстеде та ін.). Вітчизняні науковці такі проблеми лише констатували [1]. Ми також робили спробу проаналізувати проблеми етнічної ідентичності українців [2]. Що ж до загальної української та регіональної топонімії, то їі досліджували Д. Бучко, Л. Гумецька, І. Железняк, О. Карпенко, Ю. Карпенко, Л. Масенко, В. Німчук, Ю. Редько, О. Стрижак, М. Янко та ін. Проте навіть за наявності таких досліджень етнодуховна складова потребує вивчення з огляду на те, що відродження етнічного державного утворення, яке пережило кількасотрічну колонізацію, передбачає зміни зовнішніх атрибутів - елементів системи етнодуховних цінностей.

Мета статті. Відповідно до аргументованої вище актуальності таких гуманітарних проблем в Україні метою статті визначаємо дослідження особливостей формування одного з іiі регіонів - сучасної Херсонської області у площині етнодуховного конгломерату. 
Виклад основного матеріалу. Насамперед визначимось із вживанням ключового терміна «етнічний», який вибираємо замість загальноприйнятого в соціальній сфері відповідника «національний», оскільки відповідно до сучасних словникових дефініцій перший стосується власне природної спільноти («особливий вид спільності людей, яка утворилася внаслідок природного розвитку людей на основі специфічних стереотипів свідомості й поведінки. Ця біосоціальна спільнота формується і розвивається об'єктивним історичним шляхом» [3, с. 263], а другий - політичної («спільність людей незалежно від їхнього етнічного походження, об'єднаних політичними інтересами, усвідомленням своєї спільності на певній території < .. > 3 певною організацією (суверенітетом), єдиним громадянством <..> культурою i традиціями» [3, с. 523].

У другому визначенні акцентуємо увагу на словосполученні «незалежно від їхнього етнічного походження», тобто таким чином поняття «нація» втрачає свою етнічну складову. Це віяння часу, про що свідчить прибирання 3 паспортів графи «національність», орієнтація на це нових політологічних словників (аналізований нами - 2005 року), а також останні події в Україні, коли яскравими іï патріотами виявилися деякі етнічні росіяни чи вірмени, а натомість багато українців $\epsilon$ ворогами - прихованими чи відкритими (генерали в Генштабі РФ).

Можливо, така деетнічність і насправді $є$ віянням часу, внеском у тенденцію європейської чи американської глобалізації, але у світобудові існують вічні речі, як-от етнічні традиції, назви, герої та, звісно, мова. Їх незмінність найкраще спостерігається на відносно нових територіях, де етнодуховний простір формувався недовго (в історичному вимірі), що фіксувалося документально. Як приклад такого регіону наводимо Херсонщину.

Відомо й логічно розуміється, що південна частина українських земель до імперського офіційного заселення не була однозначно «порожньою», як це хочуть бачити політичні антиукраїнські сили. Відомі історики 2-ї половини XIX століття - до речі, одесити (Є. Загоровський, О. Маркевич, А. Скальковський) - відзначали, що південна територія, яку було надано для колонізації, «належала власне Запоріжжю», монархія ж не бажала сприймати ці землі як такі, що «до неї не належать», а тому бажала якнайшвидше знищити навіть натяк на якісь окремішні права: «сепаративний устрій має поступитися місцем загальноруському» [4]. Тобто ці окремішні права походять від жителів козацьких сіл і паланок - власне українців, а тому останніх можна цілком аргументовано ідентифікувати як корінне населення, основне заняття якого хліборобство [5]. Про це свідчать і топоніми, що походять від козацьких перевозів, переправ, хуторів і зимівників (Гола Пристань, Збур'ївка, Микільське, Бургунка, Дримайлівка, Тягинка, Давидів Брід, Каїри, Кам’янка, Милове, Золота Балка, Осокорівка та ін.). 
Відомо, що самодержавна політика Катерини II на той час передбачала знищення будь-якого «сепаративного устрою», а тому вимагалося застосувати всіх можливих заходів для швидшого «обрусіння» Малоросії. Можна провести паралель із більш актуальним для сучасної України повоєнним періодом (від 1946 року), коли так само на керівні посади призначалися винятково «великороси» (росіяни). Тому наприкінці XIX ст. частка цих колоністів була найбільшою саме серед адміністрації та військових (відповідно 67\% і 52\%), освітян (до 50\%), прислуги та проституток (до 50\%), і поступалася кількісно лише серед хліборобів українцям, частка яких складала там 74\% [6].

Принагідно зазначимо, що перший офіційний перепис населення імперії 1897 року фіксував етнічну приналежність за визначенням респондентом рідної (материнської) мови. Тобто маємо перше виявлення власної етнічної ідентичності, зафіксоване документально. Проте це 3 боку «малоросів», оскільки частку осіб, які визнали себе «великоросами», але при тому були етнічними українцями, неможливо було визначити. I знову напрошується аналогія 3 нашим часом, коли етнічна позиція документально вже не визначається. Отже, українцем себе може (міг) визнати той же єврей, а росіянином - українець.

Виходячи з цього, свідомими українцями на кінець XIX століття були $21 \%$ 3-поміж адміністрації та 18 \% військових. Тобто серед людей, що свідомо (наше виділення - B.Д.) визнавали себе українцями, були і дворяни, i духовенство, і купці. Що ж до другого конгломерату - «несвідомих українців» - $\epsilon$ свідчення невідомого укладача результатів перепису: малоросів у містах налічувалось всього чверть населення, «хоча всюди на вулицях і базарах серед сірого люду чулася чиста малоруська мова, а в колі середнього й вище середнього класу панує говір 3 густим диханням» (остання фонетична характеристика - особливість українського мовлення). Цей кореспондент пояснює ситуацію таким чином: «інтелігенція з малоросів, що звикла вже в домашньому житті використовувати книжну мову, переважно вважає себе не малоросами, а руськими. Те ж могло трапитися й з багатьма 3 маси малоросів, які володіють певною мірою російською мовою та бажають виділити себе від “простих хохлів". Тільки таким чином можна пояснити таку невідповідність цифр життю» [7, с. 8-9]. Знов-таки перед очами аналогія з 50-60-ми роками XX століття, коли будь-який керівник-українець усіма засобами намагався поставити себе над масою своїх земляків саме за допомогою російського мовлення. Пізніше в умовах міста це будуть робити всі - від першокурсника профтехучилища до секретаря обкому партії.

На той час у повітах мешкала більшість населення імперії, а тому частка $63,2 \%$ від усіх повітян свідчить про безперечне домінування українців (росіян - 11,34\%, румунів - 6,7\%, німців - 5,7\%). Загалом відзначаємо етноси урбаністичного типу (росіян, євреїв) і неурбаністичного (українців, молдован і німців). Варто зазначити, що євреї поступово переїжджали до міст, формуючи 
масив міщан, i А. Скальковський їх характеризує за такими демографічними рисами: серед них і приріст більший, ніж приріст «християнського населення», яке не зменшується «тільки завдяки постійному приливу сільського населення» [8, с. 41]. За аналогією відзначимо це постійне поповнення міста упродовж двох сторіч аж до сьогодні, що й зберігає проукраїнський етнічний баланс в українському місті.

Отже, можемо зробити проміжний висновок про домінування українського населення в губернії наприкінці XIX століття та про фактичне поповнення міст за рахунок саме сільського (переважно українського) населення. На той час переїзд із села був жорстко регламентований, а тому саме державний курс на колонізацію Півдня сприяв цьому. I хоча офіційно (публічно) заселення краю відбувалося іноземними колоністами та селянами 3 російських губерній, насправді ж це були переважно селяни з українських губерній.

Через 30 років, за переписом 1926 року, у місті Херсоні кількості носіїв української та російської мов дорівнялись (по 36\%), євреї склали $25,5 \%$. У селі українців було $82,6 \%$, росіян - 9,2\%, загалом в окрузі - відповідно $77,4 \%$ та $11,9 \%$ (євреїв - 6,5\%) [9]. На той час з'являється новий адміністративний конгломерат - селище міського типу, що було породженням тодішнього устрою та було орієнтоване на «пролетарську культуру». 3 часом жителів СМТ-райцентру стали фіксувати як міських, а працівників довколишніх радгоспів - як робітників, що зрештою призвело до виникнення почуття меншовартості у вихідців із села, відповідно - до зменшення їх частки та офіційного збільшення кількості робітників і міських жителів. Загалом це давало змогу піднести російську мову (як мову більшості міщан) до статусу єдиної офіційної.

Останній радянський перепис 1989 року засвідчив факт домінування української національності в Херсонській області $(75,7 \%)$. Причому, якщо в області цей відсоток зменшився після перепису 1979 року на 1\%, то в Херсоні - збільшився з 66 \% до 67,1\%, що знову-таки доводить тезу про поповнення міста за рахунок селян. Тобто мовно-етнічна ситуація за сто років принципово змінилася тільки в містах, залишившись незмінною в сільській місцевості та загалом у регіоні. Це визначається за допомогою наукового аналізу, водночас спроби втручання на користь певних політичних сил залишалися марними, відбиваючись лише на міському соціумі.

У Херсонській області наразі ці показники виявляють проблемність лише в місті. За офіційними даними, 69,2\% українців Херсона вважають українську мову рідною (у Н.Каховці - 78,8\%, Каховці - 91,3\%). У районах відповідна цифра є нижчою за 90\% лише в Генічеському - 81,9\%, а в інших - не нижча за $97 \%$, причому фіксується росіян - носіїв української мови - до 15\% (Великоолександрівський та Нововоронцовський райони) [10]. В окремих селах, де комплексно розселялися етнічні росіяни (наприклад, у Рубанівці 
Великолепетиського району), вони в третьому поколінні $€$ вже носіями української мови як функційно першої.

Ми вже зазначали в серії статей з цісї проблематики [11] об’єктивні та суб’єктивні чинники формування колізійної етномовної ситуації в південному регіоні та взагалі на більшій території України, коли українці кількісно домінують, але якісний аспект залишається на користь російської мови. Це пов'язано, звичайно, з колоніальним синдромом - комплексом меншовартості, який лише суб'єктивними чинниками знищити неможливо.

Цей комплекс формувався, по-перше, через освіту, що в місті реалізовувалася російською мовою (коли носій української мови потрапляв навіть до сільськогосподарського вишу, де мовою навчання була російська, у нього деформувалися всі генетично закладені вербальні моделі). Тому під час перепису як 1897 року, так і 1989 той селянин міг уже не ідентифікувати себе українцем. По-друге, російська мова засобів масової інформації відчутно впливала на рівень масової психіки, коли й читання книжок (згадаймо шкільний підручник «Родная литература», повністю присвячений саме російській), і писання (навіть селяни похилого віку писали листи російською мовою), і огляд кінофільмів (навіть етнографічні стрічки про Україну були російськомовними) та прослуховування естрадних пісень маніфестували якісну перевагу російської мови. По-третє, упродовж усього імперського періоду був відчутним брак українських адміністративних кадрів (у царські часи цього й не могло бути, у 20-ті роки їх було дуже мало, у повоєнний період ї до влади не допускали, а у 60-70-ті вони були вже асимільовані). Почетверте, такій етномовній асиміляції сприяла довготривала депопуляризація села та професії хлібороба, що може бути виправлена лише урядовою переорієнтацією державної економіки на сільське господарство. Можна зазначити й п’ятий чинник - мову Церкви, оскільки української мови в імперській церкві бути не могло апріорі, і взагалі - навіть у сільській місцевості кількісно домінувала Російська православна церква.

Можливо, радикальні заходи змінили б таку ситуацію швидко, але вже майже 30 років відбувається повільна еволюція, що має як позитивні (у сфері офіційного функціонування української мови як державної), так і негативні (у побутовій - неофіційній - сфері міського мовлення). Неофіційна сфера при цьому має один надто важливий аспект - мову виховання дитини, що як від матері, працівників освіти та дитячих розвивальних програм переважно $є$ російською. Проте саме в цей період формується етнічна ідентичність. Недарма ще О. Потебня зазначав, що носіїв російської мови як рідної можна вважати вже етнічними росіянами. Утім зауважимо, що радянська ідеологія, бачачи нереальність цього процесу через міцну етнічну генетику, зокрема українців, запровадила іншу ідею - створення формації так званого «радянського народу». На нашу думку, ця ідея імперіалістам вдалася, і представники 
означеного конгломерату до сьогодні складають доволі відчутну частку електорату, що загалом гальмує демократичний розвиток країни.

Відповідно система соціальних норм і настанов, моральних (духовних) цінностей «радянського народу», як усяка колишня культура (цивілізація), поступово застаріває та вироджується через свої негативні риси, що сьогодні виявляють свою абсурдність, зважаючи на світові орієнтири. Наприклад, концепція Православної церкви принципово розходиться 3 фактом непоховання Леніна, хоча ця Церква в Росії $\epsilon$ фактично синодальною складовою державного механізму, тобто могла б елементарно вирішити цю колізію.

Негативну рису виявляла й система радянської топонімії, що існувала на території України - уже декларативно незалежної держави - аж до 2014 року та була абсурдною на тлі демократичного сьогодення: ті топоніми маніфестували імена діячів тоталітарної держави, які свого часу брали участь в акціях, спрямованих саме проти українців як етносу. Таким був, скажімо, О. Цюрупа - ленінський соратник, який створив продзагони - одну з причин голодомору в Україні. I 1928 року містечко Олешки, що було позначене ще в давньоруських пам'ятках XII століття, у XVIII населене запорозькими козаками, було перейменовано на Цюрупинськ.

Натомість у Росії в 90-ті роки ХХ століття 30 великих міст (третина цієї категорії) змінили (відновили) свої назви: Свердловськ - на Скатеринбург, Горький - на Нижній Новгород, Молотов - на Перм, Ленінград - на СанктПетербург, Куйбишев - на Самару, Калінін - на Твер. При цьому 3-поміж середніх і малих міст було перейменовано лише десяту частину (так, жителі м. Ульяновська проголосували проти історичної назви Симбірськ).

В Україні ж було лише два випадки повернення історичних топонімів, але ще 1989 року: Ворошиловград - на Луганськ, Жданов - на Маріуполь. I важко було зрозуміти, чому тоді й не Кіровоград (чим Кіров для України корисніший за Жданова?). Проте ця колізія стає зрозумілою в порівнянні 3 Росією, де також Кіров тоді ще не було перейменовано на В’ятку (аналогічно перейменування міліції на поліцію, що відбулося в Україні лише через 20 років після Росії). Це все пояснюється безпосереднім впливом колишньої метрополії на колишню їі власність.

У сусідній Польщі існує Комісія переслідування злочинів проти свого народу. Аби така існувала й діяла (! - наш акцент - B.Д.) в Україні, то навряд чи існували ці топоніми вже 1989 року. Аналогічно - Дніпропетровськ i Дніпродзержинськ, «прототипи» яких Г. Петровський та Ф. Дзержинський безжально знищували українську культуру. Останній узагалі уславлений (чомусь саме чекіст, а не якийсь господарник або будівельник) у топонімах різного рівня в Україні, а його пам'ятники традиційно встановлювалися біля управлінь КДБ або МВС і стояли там аж до 2000-х років. У площині 
демократичних орієнтацій на європейські цінності інакше як абсурдом це назвати (логічно пояснити) не можна.

Топонімія Херсонщини до й від часів офіційної колонізації була переважно українською. Це, зокрема, старовинні назви козацьких поселень (до XVIII століття - Гола Пристань, Збур'ївка, Кам'янка та ін.) і переселенських громад (після XVIII століття - Копані, Новомиколаївка, Новоберислав, Чалбаси) та деякі топоніми, що передають атмосферу радянської епохи (Партизани, Індустріальне, Комунарівка, Більшовик). Загалом це все ж таки власне українські топоніми - і за формою (Білоусове, Долинське, Бабенівка Перша, Діброва, Велетенське), і за змістом (Дніпровське, Біла Криниця, Нова Зоря, Гончарне, Залізний Порт).

Відповідно до теорії цивілізацій вирізняються шість етапів соціальних трансформацій: 1) утвердження цінностей монархічної держави та православної віри як анклаву в межах української етнічної території; 2) розвиток цінностей монархічної держави та православної віри як уже приналежних російській метрополійній культурі на українській етнічній території; 3) занепад (знищення) орієнтирів монархічної держави та православної віри й утвердження «пролетарських» цінностей на основі російських духовних пріоритетів у межах української етнічної території; 4) розвиток пролетарських цінностей на основі російських духовних пріоритетів i утворення конгломерату «радянський народ»; 5) початок занепаду системи радянських духовних цінностей та відродження православних орієнтирів і традицій домінантного українського етносу 3 формальним утвердженням України як самостійної держави; 6) формування реально самостійної держави Україна із власною системою етнокультурних цінностей [2].

При цьому шостий етап перебуває наразі на половинній стадії: радянські духовні цінності ще не припинили свого впливу (разом зі своїми носіями), але водночас українські активно розвиваються - переважно у сфері офіційного мовного функціонування, коли зовнішня наочність у містах оформлюється більшою мірою державною мовою. Цей процес потребує постійного контролю та підтримки (такої, як наприклад Закон «Про забезпечення функціонування української мови як державної» 2019 року), а також розвитку в нових площинах - наприклад, аудіальної наочності та дитячої освіти. За тією ж теорією цивілізації, така ситуація є об’єктивною: хоча формально й започатковано нову постколоніальну державу, ознаки попередньої - колоніальної спостерігаються ще довгий час. При цьому суб'єктивний чинник відіграє підсилювальну чи гальмівну роль: якщо народ країни переважно стоїть за етнічну чи державну незалежність, процес розвитку буде швидким i невідворотним, якщо ж народ підвладний колоніальній пропаганді, цей процес повсякчас гальмується. 
Наприклад, представники Комісії з розгляду питань про присвоєння назв (перейменувань) вулиць і площ при Херсонській міській Раді народних депутатів неодноразово заявляли, що в місті не можна змінити жодної радянської назви, оскільки проти цього постає значна частина громадян (тобто носіїв радянської культури), і потрібен певний час для виправлення такого становища. Зрештою відбулося те, що мало відбутися ще чверть століття тому, - відповідний владний акт держави про перейменування означених міських об’єктів.

Отже, в сьогоденній Україні ще функціонує радянська (колоніальна) культура, а ії̈ представники $є$ офіційно українськими громадянами та найбільш активним електоратом (особливо на Сході). Поки що вони відчутно впливали на подальший державний розвиток (переважно як його гальмо), нині ж ситуація найбільш загадкова - може призвести як до різкого стрибка вперед, так і до різкої зупинки. Не варто забувати й про активне протистояння позитивним процесам потужної сусідньої Росії, що наразі декларує повернення імперії. Регресивні ознаки репрезентовані також і частиною народу, що не має жодних духовних орієнтацій (маргіналів), відповідно прогресивні ознаки можуть бути набуті через віру (релігію) та любов до свого генетичного етносу (націоналізм, у межах якого шануються всі етноси й гостро сприймаються імперіалізм або глобалізм).

На нашу думку, поряд із перейменуванням міських об’єктів, сприятимуть розвиткові етнічної ідентичності жителів й інші заходи:

- категоричне оформлення всієї міської візуальної інформації (реклам, афіш, офіційних назв фірм і магазинів) українською мовою із залученням матеріальних чинників - наприклад, податку на російськомовні видання, що перевищуватиме аналогічний на видання українською. Це буде стимулювати надавачів інформації оформлювати іiі державною мовою;

- сприяння поданню аудіальної інформації виключно українською мовою - із синхронним перекладом нею російськомовних інтерактивних виступів або свідомим добором українськомовних респондентів. Це буде стимулювати респондентів говорити українською (переважна їх більшість це можуть), оскільки перший варіант маніфестуватиме їх як іноземців, яких перекладають;

- переведення всіх місцевих радіостанцій, телебачення й офіційних українських сайтів виключно на державну мову - із дозованим поданням іншомовних (зокрема російськомовних) пісень. Це буде стимулювати журналістів (блогерів) доводити рівень володіння українською мовою до досконалого, а у слухачів викликатиме відчуття соціальної престижності саме цієї мови.

Такі заходи впливатимуть і психологічно на жителів України: кожен свідомий громадянин уважатиме, що не лише знання, а й фактичне використання української мови - це показник його реальної громадянськості, 
патріотичності. 3 іншого боку, кожен несвідомий громадянин (українофоб, антидержавник, маргінал тощо) відчуватиме себе чужим у цій країні - і не колоністом, а тимчасовим іноземним гостем (ще й небажаним).

В умовах демократії (предемократіі), коли всі зазначені вище прошарки українських громадян мають однакові можливості впливати на розвиток держави (або його гальмування), процес реалізації прогресивних заходів (наприклад, запропонованих нами вище) відбуватиметься (і відбувається вже) дуже повільно, із повсякчасним стишенням ходу та намаганням змінити певні просторові орієнтири. Утім головної мети вже досягнуто - формальний статус «державної незалежності України» став не лише офіційно визнаним і закріпленим, а й реальним. Одним із головних показників цієї реальності $\epsilon$ система топонімії, що була змінена в кількісному вимірі й надалі має змогу вдосконалюватися якісно, а також функційний розвиток української мови, що потребує подальшого контролю за виконанням декларованих положень.

Висновки і пропозиції. 3 вищенаведеного можна зробити кілька висновків:

- на власне колоніальній території Півдня України з початку ії масового (офіційного) заселення у XIX столітті сформувалася українська етнічна більшість, оскільки порівняно 3 іноземними колоністами та селянами 3 російських губерній селяни з українських губерній кількісно домінували. Це домінування впродовж наступних 100 років лише збільшувалося, через що логічно говорити і про домінування українських етнодуховних цінностей;

- найбільші міста Півдня - Херсон, Одеса, Миколаїв (за порядком заснування) - виявляли впродовж своєї історії проімперський характер насамперед через функціонування російської метрополійної мови в усіх сферах суспільного життя. Однак поповнення міста за рахунок сільського населення (переважно українського) формувало потенційне середовище громадян майбутньої незалежної держави, незважаючи на їх двомовність і віднесеність певної частини до «радянського народу»;

- топоніми Херсонщини завжди були переважно українськими, оскільки це давні назви козацьких і переселенських поселень. I хоча частина 3 них свого часу маніфестували радянські цінності, загалом це власне українська топонімія - за формою та змістом;

- функціонування системи радянської топонімії на території України впродовж періоду декларативної незалежності - аж до 2014 року - виявляє повну абсурдність на тлі демократичної сутності держави. Ті топоніми маніфестували імена діячів, які брали участь в акціях, спрямованих проти українців як етносу (наприклад, Ф. Дзержинського, Г. Петровського та О. Цюрупи). Тому затвердження власне українських топонімів Дніпро, Кропивницький, Олешки вважаємо локальною перемогою незалежності;

- вирішення сьогоденної соціальної колізії в Україні щодо протистояння політичних орієнтацій (проєвропейська - проросійська) перебуває у сфері 
логіки: потрібно відзначати лише тих героїв, які боролися й розвивали Україну, a не Російську імперію чи Радянський Союз. Саме їх імена мають бути відзначені в лінонімах й ойконімах як маркерах політичної орієнтації суспільства.

У подальшому плануємо досліджувати результати продовження політики етнодуховного відродження в Україні, зокрема у сферах релігії та культури.

\section{Лimepamypa:}

1. Суший О. Культурний код - домінанта ідентитету та чинник розбудови національної державності. Актуальні проблеми державного управління, педагогіки та психології. 2012. № 1(6), с. 207-211.

2. Демченко В. М. Духовні цінності Херсонської міської громади: формальний вимір. Теорія та практика державного управління і місиевого самоврядування, [online]. URL: http://www.nbuv.gov.ua [Дата звернення 26 травня 2013].

3. Політологічний словник / за ред. Головатого М. Ф., Антонюка О. В. Київ : МАУП, 2005.

4. Загоровский Е. Славянская колонизация Новороссии в XVIII в. Київ, 1913. 100 с.

5. Демченко В. М. Мовне середовище. Екстралінгвістичний нарис про Південь України. Херсон: АЙЛАНТ, 2001.212 с.

6. Первая всеобщая перепись населения Российской Империи 1897 г. XLVII. Херсонская губерния. Москва, 1904. 310 с.

7. О населении губернии по данным всеобщей переписи 1897 г. Херсон, 1905. 67 с.

8. Скальковский А. Одесса 84 года тому назад и теперь. Одесса, 1844. 60 с.

9. Одеська область (адресна й довідкова книга) на 1935 р. Одеса, 1934. 327 с.

10. Херсонський обласний державний архів. Ф.Р 2000. Оп. 4. Спр. 7. Арк. 11-29.

11. Демченко В. М. Формування етномовної ситуації на Півдні України: ретроспектива та перспектива. SienceRise : scientific journal, [online]. 2014. 5(1). P. 75-79. URL: http://journals.uran.ua/sciencerise/issue/view/2060 [Дата звернення 19 травня 2014].

\section{References:}

1. Sushyy O. (2012). Kul'turnyy kod - dominanta identytetu ta chynnyk rozbudovy natsional'noyi derzhavnosti [Cultural code - the dominant of the identity of that official of the state of national authority]. Aktual'ni problemy derzhavnoho upravlinnya, pedahohiky ta psykholohiyi Actual problems of sovereign government, pedagogy and psychology, 1(6), s. 207-211. [in Ukrainian].

2. Demchenko V. M. (2013). Dukhovni tsinnosti Khersons'koyi mis'koyi hromady: formal'nyy vymir [Spiritual values of the Kherson city community: a formal vimir]. Teoriya ta praktyka derzhavnoho upravlinnya i mistsevoho samovryaduvannya - Theory and practice of sovereign government and self-determination, [online] Retrieved from http://www.nbuv.gov.ua 2013/5/26. [in Ukrainian].

3. Politolohichnyy slovnyk [Political dictionary]. (2005). Kyiv : MAUP. [in Ukrainian].

4. Zahorovskyy E. (1913). Slavyanskaya kolonyzatsyya Novorossyy v XVIII v. [Slavic colonization of New Russia in the XVIII century]. Kyiv, 1913. 
5. Demchenko V. M. (2001). Movne seredovyshche. Ekstralinhvistychnyy narys pro Pivden' Ukrayiny [Linguistic environment. Extralinguistic essay about the South of Ukraine]. Kherson: AYLANT. [in Ukrainian].

6. Pervaya vseobshchaya perepys' naselenyya Rossyyskoy Ymperyy 1897 h. [The first general census of the population of the Russian Empire in 1897] (1904), XLVII. Khersonskaya hubernyya. Moskva. [in Russia].

7. O naselenyy hubernyy po dannym vseobshchey perepysy $1897 \mathrm{~h}$. Kherson [About the population of the province according to the data of the 1897 census of Kherson] (1905). [in Russia].

8. Skal'kovskyy A. Odessa 84 hoda tomu nazad y teper' [Odessa 84 years ago and now] (1844). Odessa. [in Russia].

9. Odes'ka oblast' (adresna y dovidkova knyha) na 1935 r. [Odessa region (address of the first book) for 1935 p.]. (1934). Odesa. [in Russia].

10. Khersons'kyy oblasnyy derzhavnyy arkhiv [Kherson Regional State Archive]. F.R 2000. Op. 4. Spr. 7. Ark. 11-29. [in Ukrainian].

11. Demchenko V. M. Formuvannya etnomovnoyi sytuatsiyi na Pivdni Ukrayiny: retrospektyva ta perspektyva [Formuvanny etnomnovo situation in Ukraine, Ukraine: retrospective and perspective]. (2014). SienceRise : scientific journal, [online], 5(1). P. 75-79. Retrieved from http://journals.uran.ua/sciencerise/issue/view/2060 2014/5/19. [in Ukrainian]. 